\title{
Culture medium fatty acid withdrawal prompts insulin producing cell death
}

\begin{abstract}
Fatty acids (FAs) are important components of cell membranes and precursors of bioactive molecules. Deficiency of FAhas been associated with development of diseases and tissue damage in animal models. FAs regulate several cell functions including insulin secretion. We investigated the effects of FA withdrawal in culture medium on insulin producing cell (RINm5F) metabolism, survival, and response to death stimuli. Cells were cultivated in lipid-reduced fetal bovine serum (LRS) medium for 24,48 or $72 \mathrm{~h}$. Cell proliferation was measured by $\mathrm{BrdU}$ incorporation and glucose metabolism by $14 \mathrm{CO}_{2}$ production. Production of reactive oxygen species (ROS) was determined using dichlorofluorescein diacetate assay. Cells were exposed to death inducers to evaluate the effect of FA deprivation on RINm5F cell survival and susceptibility to death induction. Loss of plasma membrane integrity, DNA fragmentation, phosphatidylserine externalization and activation of caspases were analyzed by flow cytometry. The removal of FAs from the culture medium increased the number of dead cells as assessed by loss of plasma membrane integrity and occurrence of DNA fragmentation. Cells cultured in LRS exhibitedhigher cell death rates as compared to those cultivated with conventional serum. Cultivation in LRS for 48hours increased phosphatidylserine externalization, caspase activation, ROS production and glucose oxidation. FA deprivation induced RINm5F cell death through apoptosis and exacerbated the cell death response to death stimuli. Cell death was associated with changes in generation of ROS and glucose oxidation.
\end{abstract}

Keywords: pancreatic b-cells, fatty acids, apoptosis, staurosporine, UV radiation, glucose oxidation, ROS production
Volume 5 Issue 3 - 2017

\author{
Mariana Papaleo Rosim,' Nunes V,' ${ }^{2}$ Lenzen $\mathrm{S},{ }^{3}$ \\ Curi R,' Azevedo Martins AK ${ }^{2}$ \\ 'Institute of Biomedical Sciences, Brazil \\ ${ }^{2} \mathrm{~S} c h o o l$ of Arts, Sciences andhumanities, University of Sao Paulo, \\ Brazil \\ ${ }^{3}$ Institute of Experimental Diabetes Research,hannover Medical \\ School, Germany
}

\begin{abstract}
Correspondence: Mariana Papaleo Rosim, Institute of Biomedical Sciences, Rua Padre Artur Someni, 08, ap I I4, Vila Madalena, Sao Paulo SP, 05443 030, Brazil, Tel 55 II 984I7-9532, Email mariana.rosim@usp.br
\end{abstract}

Received: June 23, 2017 | Published: August 28, 2017

\begin{abstract}
Abbreviations: FA, fatty acids; GSIS, glucose stimulated insulin secretion; ATP, adenosine triphosphate; MTT, 3-.4,5-Dimethylthiazol2yl-2,5-diphenyltetrazolium bromide thiazolyl blue; DMSO, dimethyl sulfoxide; FCS, fetal calf serum; CS, conventional fetal bovine serum; LRS, lipid reduced serum; DNA, deoxyribonucleic acid; BrdU, bromodeoxyuridine; TMB, tetrametilbenzidine; PBS, phosphate buffered saline; DCFDA, dichlorofluorescein diacetate; UV, ultraviolet light; PI: propidium iodide; PSPhosphatidylserine; FITC, fluorescein isothiocyanate; IL- $1 \beta$, interleukin $1 \beta$; ROS, reactive oxygen species; TRAIL, tumor necrosis factor-related apoptosisinducing ligand; ADP, adenosine diphosphate.
\end{abstract}

\section{Introduction}

Fatty acids (FAs) are important components of cell membranes and play a key role in membrane microdomains (e.g. lipid rafts) formation. ${ }^{1}$ FAs control production of pro-inflammatory and antiinflammatory mediators. ${ }^{2}$ and expression of genes and cell signaling. ${ }^{3}$ Moreover, FAs are involved in a number of cellular processes such as cell proliferation and differentiation, as observed in chondrocytes. ${ }^{4}$ and skeletal muscle cells. ${ }^{5}$ They are also able to modulate apoptosis and production of reactive oxygen species in endothelial cells. ${ }^{6}$ and glucose stimulated insulin secretion (GSIS) in b-cells. ${ }^{2,7}$

GSIS is associated with an increase in glycolytic and tricarboxylic acid cycle activity and generation of metabolic-secretion factors. ${ }^{8}$ The major pathways of GSIS is the one in which glycolysis derived ATP plays a key role in the closure of KATP channels, resulting in the depolarization of the plasma membrane, opening of Ca voltagedependent channels and insulin secretion. ${ }^{7,8}$

FA signaling on pancreatic b-cells can occur through two different mechanisms: through the GPR40 receptor,highly expressed in pancreatic b-cells, which increases the intracellular $\mathrm{Ca}^{2+}$ concentration and plays an important role in GSIS. ${ }^{9-11}$ or indirectly through intracellular FA metabolism and generation of lipid signaling compounds as long-chain Acyl-CoA..$^{3,12}$ which are involved in pancreatic $\beta$-cell exocytosis activity. ${ }^{13}$

Studies using MIN6 and INS-1 insulin-producing cell lineshave shown increases in insulin secretion induced by long-chain FAs through GPR40 receptor activity., ${ }^{9,14}$ Increase in insulin secretion was also observed in isolated mice pancreatic islets treated with polyunsaturated linoleic and a-linolenic acids. ${ }^{15}$ Dogs treated with sodium oleate by direct infusion into the circulation also showed increased insulin secretion. ${ }^{16}$ Inhumans, a $24 \mathrm{~h}$ low-grade lipid infusionhas the same effect observed in dogs. ${ }^{17}$ Although acute exposure to FAs can potentiate GSIS, chronical exposure can impair GSIS, as observed in isolatedhuman islets exposed to palmitate ${ }^{18}$ or a mixture of oleic and palmitic acids (2:1), ${ }^{19}$ and can even lead pancreatic b-cell to apoptosis. ${ }^{3,20}$

On the otherhand, it was shown that isolated pancreatic islets from $24 \mathrm{~h}$ fasted ratshad an reduced insulin secretion when stimulated by glucose, but these results were not observed in vivo, unless animal were previously treated with an antilipolytic agent, suggesting that FAs are essential for a suitable insulin response. ${ }^{21}$

Although the effects of FAs on pancreatic b-cell functions. . $^{3,11,14-20}$ have been well documented, the molecular consequences of FA deficiency on pancreatic b-cell function remain to be clarified. Some studieshave already reported the relationship of specific nutrient deficiencies with posteriorhigh risk of diabetes andhyperglycemia, ${ }^{22-24}$ however; only few of them approach the cellular mechanisms of b-cell 
response to the deficiency conditions..$^{25}$ We studiedherein the effect of FA deprived serum, the only source for FA in the culture conditions, on insulin-producing RINm5F cell function and death. We report for the first time that FA withdrawal inhibits cell proliferation and causes cell death by apoptosis.

\section{Material and methods}

\section{Reagents}

RPMI-1640 medium,hEPES, penicillin and streptomycin were purchased from Invitrogen (Carlsbad, CA, USA). Lipid-reduced fetal bovine serum was purchased fromhyClone (South Logan, Utah, EUA). Propidium iodide was purchased from ICN Biomedicals (Costa Mesa, CA, USA), sodium bicarbonate from Labsynth Products (Diadema, SP, Brazil), MTT, DMSO, 2-mercaptoethanol and sodium pyruvate from Sigma-Aldrich Co. (St. Louis, MO, USA) and staurosporine from Invitrogen Corporation (Camarillo, CA, USA). Cell culture additions (e.g. culture flasks, plates and conical tubes) were purchased from Corning (Corning, NY, USA).

\section{Cell lines culture conditions}

RINm5F and INS-1E cell lines were obtained from the Institute of Clinical Biochemistry of thehannover Medical School (Hannover, Germany). The RINm5F cell line is a clone derived from the parent RIN-m cells (derived from a rat insulinoma). These cells produce and release insulin but, unlike the parental cell line, they do not produce somatostatin. Cells were cultured in RPMI-1640 medium containing $11.1 \mathrm{mM}$ glucose and $10 \%(\mathrm{v} / \mathrm{v})$ fetal calf serum (FCS). The medium was supplemented with glutamine $(2 \mathrm{mM})$, hEPES $(20 \mathrm{mM})$, streptomycin $(10,000 \mathrm{mg} / \mathrm{mL})$, penicillin $(10,000 \mathrm{UI} / \mathrm{mL})$ and sodium bicarbonate $(24 \mathrm{mM})$.

INS-1E cell line, established from a radiation-induced rat islet cell tumor, were cultured in RPMI-1640 medium containing 10\% (v/v) FCS and supplemented with glutamine $(2 \mathrm{mM})$, hEPES $(10 \mathrm{mM})$, streptomycin $(10,000 \mathrm{mg} / \mathrm{mL})$, penicillin $(10,000 \mathrm{UI} / \mathrm{mL})$, sodium pyruvate $(1 \mathrm{mM})$ and 2-mercaptoethanol $(50 \mathrm{mM})$.

Cells were maintained in an incubator (Sanyo, Middlesex, UK) with ahumidified atmosphere at $37^{\circ} \mathrm{C}$ and $5 \% \mathrm{CO}_{2}$. For the experiments, cells were seeded in culture plates and maintained with medium containing conventional fetal bovine serum (CS) for $8 \mathrm{~h}$. After this period, a culture medium without FCS replaced the previous one and cells were then maintained under this condition overnight. Afterwards, cells were cultured with either CS or lipid-reduced serum (LRS) for 24,48 or $72 \mathrm{~h}$.

\section{Cell proliferation assay}

The technique of bromodeoxyuridine (5-bromo-2'-deoxiuridine), a pyrimidine analog to thymidine, which is selectively incorporated into nuclear DNA of proliferating cells, was used to estimate cell proliferation. The quantification of incorporated BrdU in newly synthesized DNA was performed by immunohistochemistry using anti-BrdU antibodies (Cell Proliferation Kit ELISA, BrdU, Roche Applied Science, Mannheim, Gernany), according to the manufacturer's instructions. Briefly, after cultivation with medium containing CS or LRS for 24,48 or $72 \mathrm{~h}$, cells were incubated with BrdU (10mM) for $2 \mathrm{~h}$. After this period, cells were fixed with Fix Denat solution, which causes DNA denaturation, exposing the incorporated BrdU for immunodetection. After 30minutes, cells were incubated with anti-BrdU antibody conjugated with peroxidase for 90 minutes.
For anti-BrdU quantification, TMB (tetrametilbenzidine) peroxidase substrate was added for $20 \mathrm{~min}$ and afterwardsh2SO4 $(25 \mathrm{~mL}$ of $1 \mathrm{M}$ solution) was added to stop reaction. The results were obtained by spectrophotometry $(562 / 650 \mathrm{~nm})$.

\section{Glucose oxidation measurement}

Glucose oxidation was determined as previously described by Leighton et al. ${ }^{26}$ Andhirabara et al. ${ }^{27}$ Briefly, after being cultured with LRS or CS for 24,48 , or $72 \mathrm{~h}$, RINm5F cells (3x106per well) were incubated with PBS containing $0.3 \mu \mathrm{Ci} / \mathrm{mL}$ D-.U-14C-glucose, for 1hour. After the incubation period, $14 \mathrm{CO}_{2}$ production (measured as $14 \mathrm{CO}_{2}$ release from.U-14C-glucose decarboxylation) was determined in a Packard Tri-Carb-2100TR liquid scintillation counter (PerkinElmer Life Sciences., Boston, MA).

Determination of production of reactive oxygen species (ROS) and nitrosative species

To measure the generation of ROS and nitrosative species, $2 \times 104$ cells were seeded onto 96 -well black plates and cultured for 24,48 and $72 \mathrm{~h}$. The cells were then pre-incubated with $10 \mu \mathrm{M}$ dichlorofluorescein diacetate DCFDA for $30 \mathrm{~min}$ at $37^{\circ} \mathrm{C}$. The medium containing DCFDA was discarded and fresh medium was added with the respective fetal serum-CS or LRS. After incubation for $24 \mathrm{~h}$, the plates were analyzed at $480 / 520 \mathrm{~nm}$ excitation/emission using the fluorescence reader Victor2 1420 Multilabel Counter (Perkin Elmer, Fremont, CA). The results were normalized to the number of viable cells and expressed as relative fluorescence units.

\section{Treatment with either UV radiation or staurosporine}

After cultivation with either CS or LRS for 24,48 and $72 \mathrm{~h}$, RINm5F cells were exposed to UV radiation for $10 \mathrm{~min}$ or treated with staurosporine $(100 \mathrm{nM})$ during $24 \mathrm{~h}$ for $10 \mathrm{~min}$. Staurosporine was dissolved in ethanol. The final concentration of ethanol in culture medium did not exceed $0.05 \%$ that is not toxic to the cells 28 .

\section{Cell membrane integrity assay}

After cultivation with either CS or LRS and exposure either to UV or staurosporine, RINm5F cells were trypsinized, collected and centrifuged at $1,000 \mathrm{rpm}$ for $5 \mathrm{~min}$ at $4^{\circ} \mathrm{C}$. The pellet was suspended in $500 \mathrm{~mL}$ phosphate-buffered saline (PBS) and $50 \mathrm{~mL}$ propidium iodide (PI) solution $(50 \mathrm{mg} / \mathrm{mL}$ in PBS) were added. Cells were analyzed using a FACScalibur flow cytometer (Becton Dickinson, San Juan, CA, USA). Since PI is ahighly water-soluble fluorescent compound, it cannot pass through intact membranes and so it is not found in viable cells. Fluorescence was measured using the FL2 channel (orangered fluorescence-585/42nm). Ten thousand events were analyzed per experiment. Cells with PI fluorescence were then evaluated by using the Cell Quest software (Becton Dickinson).

\section{DNA fragmentation assay}

DNA fragmentation was analyzed by flow cytometry after DNA staining with PI according to method previously described. ${ }^{29}$ After cultivation with either CS or LRS and exposed to either UV or staurosporine, RINm5F cells were trypsinized, collected and centrifuged at $1,000 \mathrm{rpm}$ for $5 \mathrm{~min}$ at $4^{\circ} \mathrm{C}$. The pellet was suspended in $300 \mathrm{~mL}$ solution containing $50 \mathrm{mg} / \mathrm{mL}$ PI, $0.1 \%$ sodium citrate, and $0.1 \%$ Triton-X-100, which permeabilized cells allowing the dye to be promptly incorporated into DNA. PI intercalates between the bases with little or no sequence preference. ${ }^{29}$ Fluorescence was measured 
and analyzed as described above.

\section{INS-I E viability assay}

The tetrazolic MTT (3-.4,5-dimethylthiazol-2yl-2,5diphenyltetrazolium bromide thiazolyl blue) salt was used to measure the viability of cells cultured in the absence of FA. INS-1E cells were collected by trypsinization and seeded in 96 wells plates, and grown with CS or LRS for 24,48 or $72 \mathrm{~h}$. The medium was then discarded and $100 \mu \mathrm{L}$ solutions with 10 parts of Krebs-Ringer buffer and 1 part MTT $(5 \mathrm{mg} / \mathrm{mL}$ in PBS) was added. The tetrazolium salt is cleaved by mitochondrial dehydrogenases, resulting in formation of formazan crystals, soluble only in organic solvents. This cleavage occurs in live cells only 30 . After $1 \mathrm{~h}$, MTT solution was discarded and $100 \mathrm{~mL}$ of DMSO (dimethyl sulfoxide) were added. The cell viability was measured by spectrophotometry $(562 / 650 \mathrm{~nm})$.

\section{Phosphatidylserine externalization assay}

Phosphatidylserine (PS) externalization assay was performed in RINm5F cells grown in the absence or presence of FAs. Annexin $V$ was used to determine PS externalization. This protein binds to negatively charged phospholipids as it is PS. The Annexin V Apoptosis Detection Kit was used (sc-4252 AK, Santa Cruz Biotechnology) to carry out this assay.

Cells were treated with trypsin and centrifuged at 1,200rpm for $10 \mathrm{~min}$. The supernatant was discarded and cells were suspended in $200 \mathrm{~mL}$ buffer. Five mL FITC (fluorescein isothiocyanate) conjugated with annexin were added in each sample as well as $20 \mathrm{~mL}$ PI. Afterwards, the cells were incubated in the dark at room temperature for $15 \mathrm{~min}$. Cells were analyzed by flow cytometry. Viable cells did not present fluorescence either for PI or FITC. Cells undergoing necrosis flourished to both fluorophores whereas those on apoptosis flourished to FITC only 31 .

\section{Activation of caspases 3, 8, 9 and I 2}

Activation of caspases 3,8 and 9 was assessed in RINm5F cells cultivated with either LRS or CS for 24 or $48 \mathrm{~h}$ using Red Caspase-3, -8 and -9 Staining Kits (PromoCell, heidelberg, Germany), according to the fabricant's instruction. After staining and washing, cell suspensions were immediately submitted to analysis in the CyFlow ML cytometer (Partec, Münster, Germany). A total of 20,000 events were acquired. Results were analyzed by FlowJo software (Tree Star, Ashland, OR). The results were expressed as percentage of positive cells grown with CS.

\section{Statistical analysis}

Results are expressed as means + SEM. Statistical analyses were carried out using one-way ANOVA followed by Tukey's post-test for multiple comparisons. Prism analysis program (Graphpad, San Diego, CA, USA) was used and differences were considered significant for $\mathrm{p}<0.05$.

\section{Results}

\section{Cell proliferation}

FA withdrawal decreased cell proliferation by 60 and $80 \%$ after 48 and $72 \mathrm{~h}$ in culture, respectively (Figure 1).

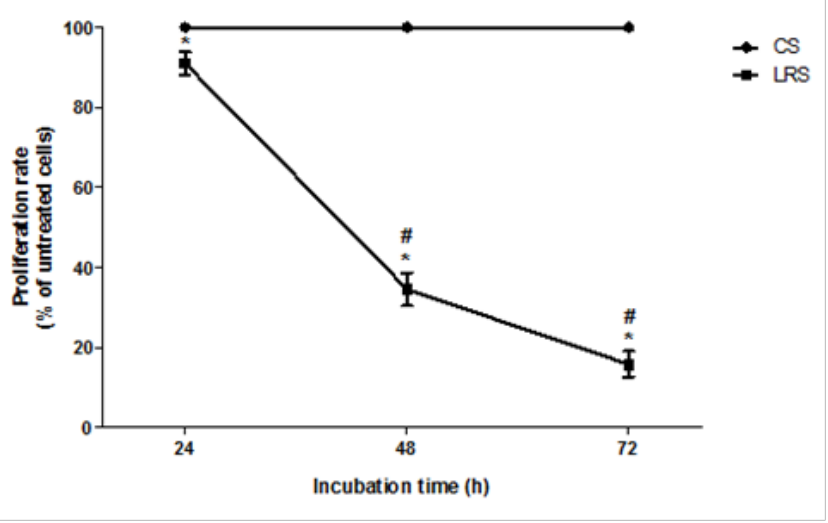

Figure I Proliferation rates of RINm5F cells cultured in the presence of either conventional serum (CS) or lipid reduced serum (LRS). Cells $\left(2 \times 10^{4}\right.$ per sample) were grown with either CS or LRS for 24,48 or $72 \mathrm{~h}$. After cultivation, cells were incubated with $\mathrm{BrdU}$ for $2 \mathrm{~h}$. Incorporated $\mathrm{BrdU}$ in newly synthesized DNA was determined by immunohistochemistry. Results are presented as means \pm SEM of four experiments in triplicates. Results were analyzed by ANOVA and Tukey's post-test and differences were considered significant at $p<0.05$. *Statistically different from the CS group; "Statistically different from the previous period.

\section{Glucose metabolism and production of reactive oxygen species}

Glucose oxidation was measured in RINm5F cells cultured for 24, 48 and $72 \mathrm{~h}$ (Figure 2). Conversion of $\mathrm{U}^{1}{ }^{14} \mathrm{C}$-glucose to ${ }^{14} \mathrm{CO}_{2}$ was significantly increased (by 2.5 -fold) in cells cultured with LRS for $72 \mathrm{~h}$ as compared to the CS condition.

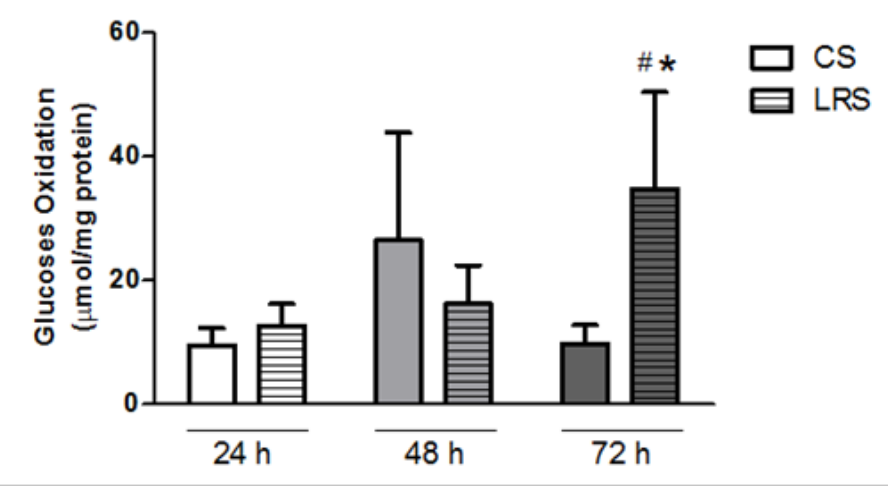

Figure 2 Glucose oxidation in RINm5F cultured in the presence of either conventional serum (CS) or lipid reduced serum (LRS). Cells $\left(3 \times 10^{6}\right.$ cells per sample) were grown with either CS or LRS for 24,48 or $72 \mathrm{~h}$. After cultivation, cells were incubated with $\left[\mathrm{U}-{ }^{14} \mathrm{C}\right]$-glucose. ${ }^{14} \mathrm{CO}_{2}$ production was then measured. Results are presented as means \pm SEM of three experiments in triplicates. Results were analyzed by ANOVA and Tukey's post-test and differences were considered significant at $p<0.05$. *Statistically different from the CS group; "Statistically different from the previous period.

Generation of reactive oxygen species (ROS) in RINm5F cells was measured through oxidation of DCFDA (Table 1). A marked increase in production of ROS was observed in cells cultured with LRS for 48 (15-fold) and 72 (50-fold)h as compared to CS.

Cells $\left(2 \times 10^{4}\right)$ were pre-incubated with dichlorofluorescein diacetate for $30 \mathrm{~min}$ and then cultured with either CS or LRS for 
24,48 or $72 \mathrm{~h}$. After cultivation, production of ROS was analyzed by fluorescence. Results are presented as means \pm SEM of five experiments in triplicates, normalized using the number of viable cells and expressed as relative fluorescence units. Results were analyzed by ANOVA and Tukey's test and differences were considered significant at $\mathrm{p}<0.05$. *Statistically different from CS; "Statistically different from the previous period.

Table I Production of reactive oxygen species (ROS) in RINm5F cells cultured in the presence of either conventional serum (CS) or lipid reduced serum (LRS) for 24,48 , or 72 hours

\begin{tabular}{llll}
\hline & $\mathbf{2 4 h}$ & $\mathbf{4 8 h}$ & $\mathbf{7 2 h}$ \\
\hline CS & $18.0+4.2$ & $24.3+6.4$ & $36.5+6.9$ \\
LRS & $48.6+14.6$ & $721.5+351.5^{*}, \#$ & $2036.4+10.3^{*}, \#$ \\
\hline
\end{tabular}

\section{Effect of LRS on cell death parameters}

Reduction of FA in the culture medium for $48 \mathrm{~h}$ increased (by two-fold) the number of RINm5F cells with phosphatidylserine (PS) externalization, one of the main features of apoptotic cells (Figure 3).

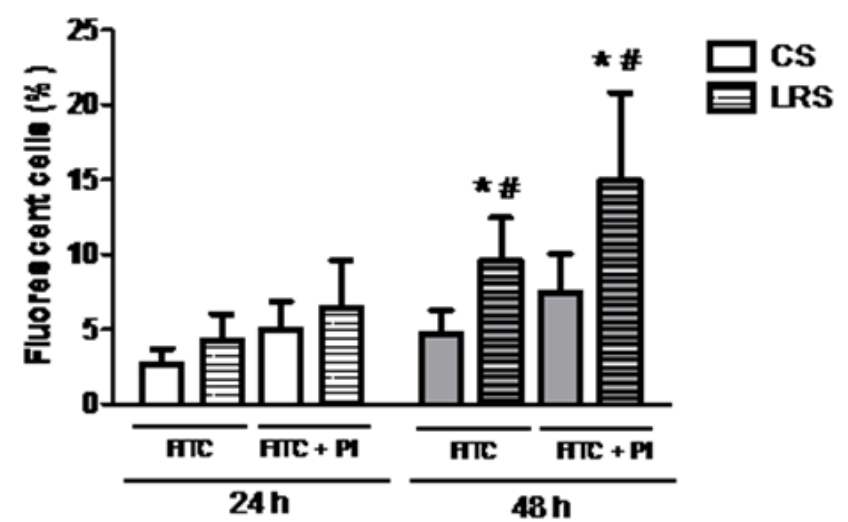

Figure 3 Percentage of RINm5F cells with phosphatidylserine (PS) externalization after 24 or $48 \mathrm{~h}$ in the presence of either conventional serum (CS) or lipid reduced serum (LRS). Cells $\left(8 \times 10^{5}\right.$ per sample) were grown with either CS or LRS for 24 or 48 h. After cultivation, cells were incubated with FITC and PI and were analyzed by flow cytometry. Results are presented as means \pm SEM of four experiments in triplicate. Results were analyzed by ANOVA and Tukey's test and differences were considered significant at $p<0.05$. *Statistically different from CS group; "Statistically different from previous periods.

PI, Propidium lodide; FITC, Fluorescein Isothiocyanate.

A decisive step of cell commitment to apoptotic death is an activation of caspases. We measured the activation of caspases 3,8 and 9 in RINm5F cells cultured with CS or LRS (Figure 4). Activation of these caspases was significantlyhigher after 48h in LRS conditions in comparison to $24 \mathrm{~h}$. There was no detectable caspase activation in CS cultured cells.

RINm5F cell death response to LRS incubation and treatments with either UV radiation or staurosporine

LRS decreased the number of viable RINm5F cells by $30 \%$ and $75 \%$, after 48 and $72 \mathrm{~h}$, respectively (Figure $5 \mathrm{~A}$ ). Lipid deprivation per se also caused an augmentation in the number of cells with fragmented DNA (by $40 \%$ ) after $72 \mathrm{~h}$ in culture (Figure 5B).
The exposure to UV radiation for 10 min caused a significant decrease in the proportion of cells with intact plasma membrane after being cultivated with LRS for 24 and $72 \mathrm{~h}$ by $70 \%$ and $95 \%$, respectively. The UV radiation effect was $20 \%$ less pronounced in CScultured cells after $24 \mathrm{~h}$ in comparison to LRS conditions (Figure 5A).

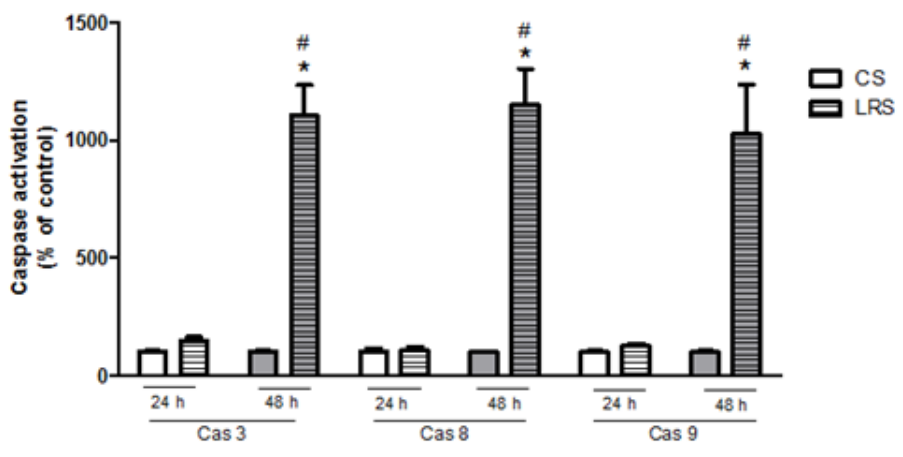

Figure 4 Activation of caspases 3, 8 and 9 in RINm5F cells cultured in the presence of either conventional serum (CS) or lipid reduced serum (LRS) for 24 or $48 \mathrm{~h}$. Cells $\left(1 \times 10^{6}\right)$ were grown with CS or LRS for 24 or $48 \mathrm{~h}$. After cultivation, caspase activation was measured by CyFlow ML cytometry. Results are presented as means \pm SEM of four experiments in triplicates. Results were analyzed by ANOVA and Tukey's test and differences were considered significant at $p<0.05$. *Statistically different from the CS group; \#Statistically different from the previous period.
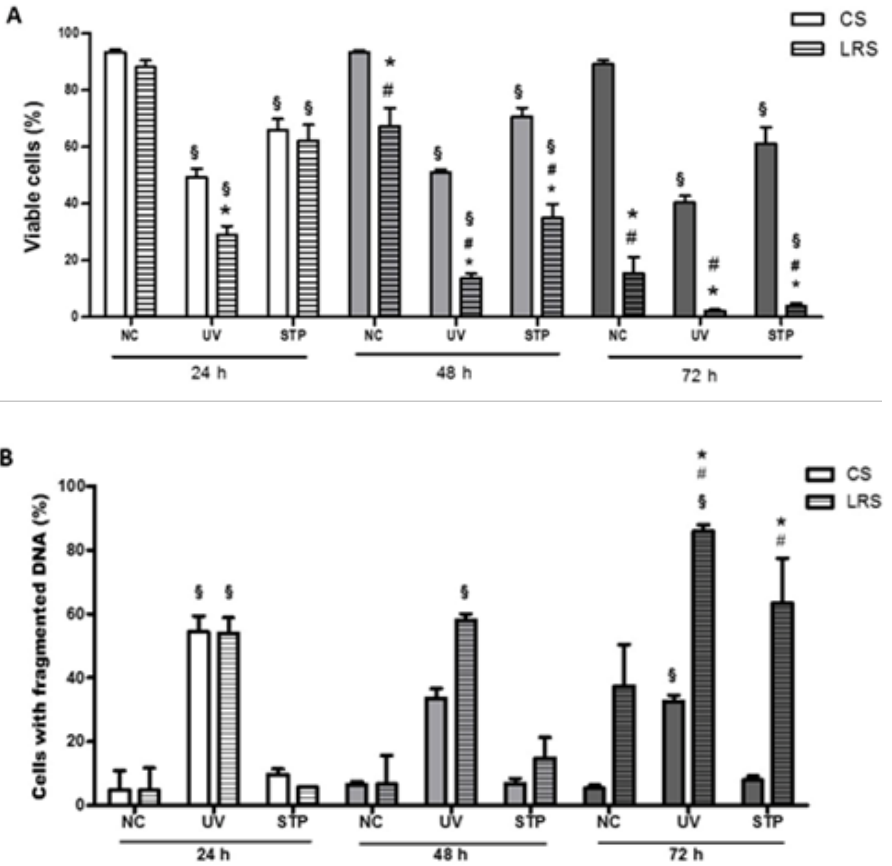

Figure 5 Effect of either UV radiation or staurosporine (STP) on RINm5F cell viability and DNA fragmentation. Cells exposed to UV radiation for $10 \mathrm{~min}$ or staurosporine $(100 \mathrm{Nm})$ for $24 \mathrm{~h}$ were grown with convention serum (CS) or lipid reduced serum (LRS) for 24,48 or $72 \mathrm{~h}$. Afterwards, cells were analyzed concerning plasma membrane integrity $(A)$ and DNA fragmentation (B) by flow cytometry. Results are presented as means \pm SEM of four to seven experiments in triplicate. Results were analyzed by ANOVA and Tukey's post-test and differences were considered significant at $p<0.05$. ${ }^{\text {SStatistically different from }}$ cells not challenged with UV radiation or staurosporine; *Statistically different from the CS group; "Statistically different from the previous period.

NC, non-treated cells; UV, ultraviolet radiation; STP, starurosporine.

Exposure to UV radiation increased the proportion of cells with 
DNA fragmentation in both culture conditions (CS or LRS). After $24 \mathrm{~h}$ of UV light exposure, more than $50 \%$ of both CS- and LRScultured cells presented DNA fragmentation (Figure 5B). After $48 \mathrm{~h}$ of UV radiation, a decreased number of cells with fragmented DNA cultured in CS were observed. The percentage of cells with DNA fragmentation did not change in LRS-culture conditions after $48 \mathrm{~h}$ in comparison to $24 \mathrm{~h}$. After $72 \mathrm{~h}$ in CS conditions, the percentage of cells with fragmented DNA was similar to that observed after $48 \mathrm{~h}$. The percentage of cells with fragmented DNA was significantlyhigher (about 25\%) after 24 and $48 \mathrm{~h}$ in LRS cultured cells.

Treatment with 100nM staurosporine caused a similar decrease in the number of viable cells in both CS- and LRS-culture conditions after $24 \mathrm{~h}$. The sensitivity to staurosporine did not become more pronounced after 48 and $72 \mathrm{~h}$ in CS culture,however, for LRS-cultured cells the percentage of dead cells was increased by $35 \%$ after $48 \mathrm{~h}$ as compared with $24 \mathrm{~h}$. Under LRS conditions, the proportion of viable cells was reduced to $5 \%$ only after $72 \mathrm{~h}$ (Figure $5 \mathrm{~A}$ ). Staurosporine caused a significant increase in the number of cells with fragmented DNA after $72 \mathrm{~h}$ in LRS (by $65 \%$ ) or in CS- (by $38 \%$ ) conditions (Figure 5B).

The susceptibility of insulin-producing cells to FAs withdrawal in the culture medium was also tested in INS-1E linage, by MTT assay. As observed in RINm5F cells, there was a decrease in cell viability after 24,48 and $72 \mathrm{~h}$ of cultivation in LRS, when compared to cultivation in conventional serum (Table 2).

Table 2 Viability analysis of INS-IE cells grown with conventional and lipid reduced FBS for 24,48 e $72 \mathrm{~h}$

\begin{tabular}{llll}
\hline & $\mathbf{2 4 h}$ & $\mathbf{4 8 h}$ & $\mathbf{7 2 h}$ \\
\hline CS & $100+2.93$ & $100+2.23$ & $100+2.35$ \\
LRS & $88.41+2.43^{*}$ & $69.16+3.12^{* \#}$ & $61.95+4,26 * \#$ \\
\hline
\end{tabular}

Cells $\left(2 \times 10^{4}\right)$ were cultured with either CS or LRS for 24,48 or $72 \mathrm{~h}$. After cultivation, cells were incubated with MTT solution and cell viability was determined by spectrophotometry. Results are presented percentage means \pm SEM of five experiments in triplicates, normalized as percentage of CS group of the same time and expressed as relative fluorescence units. Results were analyzed by ANOVA and Tukey's test and differences were considered significant at $\mathrm{p}<0.05$. *Statistically different from CS; "Statistically different from the previous period.

\section{Discussion}

Althoughhumans are able to synthesize a number of FAs, cholesterol and lipid-derivatives under physiological conditions, diet is the main source of lipids for the body. Furthermore, as some FAs cannot be synthesized (essential FAs), its abundance in the cell is exclusively dependent on exogenous supply. ${ }^{32-34}$ The impact of a diet deficient in essential fatty acids was studied in the beginning of the past century in animal models; the aim was to study the effects of vitamin E deficiency and, since this is a lipophilic compound, animals were exposed to a diet free of lipids, which resulted in injuries to the skin and tail, growth impairment andhair capillary fragility, among others. ${ }^{35}$ These symptoms were reversed by lipid administration but not by vitamin E replacement.

Therefore, cells can produce some FAs but do not generate essential polyunsaturated FAs, which play an important role in plasma membrane domain formation and fluidity, production of eicosanoids and activation of signaling transduction and transcriptional factors. ${ }^{36,37}$
Under deficiency of FAs, there would be an increase in the proportion of saturated FAs that are associated with cytolipotoxicity. ${ }^{28}$

Although cultured pancreatic b-cells can produce FAs from glucose..$^{38}$ evidence is presentedhere that withdrawal of fatty acids from tissue culture medium promotes RINm5F cell death and increases the susceptibility of these cells to death inducers, as observed in the protein deficiency. The results presentedherein point out that fatty acids are involved in RINm5F cell proliferation, glucose metabolism and survival.

Undernutrition effects in pancreatic b-cells were also studied by Merezak et al. ${ }^{39}$ in which b-cells from fetus of rats fed a protein restricted-diet exhibited ahigher apoptotic rate than the controls, when challenged in culture with a nitric oxide donor or IL-1 $\beta$. Garofano et al. ${ }^{24}$ showed that prolonged malnutrition until weaning impairs b-cells development but not b-cells proliferation. Subsequent re-nutrition is followed by increased beta-cell proliferation but this is insufficient to fully restore beta-cell mass.

FAs are important plasma membrane components and a source of ATP through the b-oxidation pathway in pancreatic b-cells. ${ }^{40}$ Therefore, cultivation in the absence of FAs would be expected to reduce cell proliferation and increase glucose oxidation as observed. In addition, cultivation in the absence of FA also induced RINm5F death as indicated by loss of plasma membrane viability and DNA fragmentation, and ROS production.

DNA fragmentation, PS externalization and caspase activation arehallmarks of the apoptotic process. ${ }^{41}$ The changes induced by LRS on these parameters observed are quite consistent. This raised the question about the underlying mechanisms. Considering that pancreatic b-cells are recognized to behighly susceptible to oxidative stress due to low expressions and activities of the antioxidant enzymes e.g. catalase and superoxide dismutase,,${ }^{42,43}$ the starting point could be the production of ROS, observed already after $24 \mathrm{~h}$ of cultivation in medium without FAs that became even more significant after 48 and $72 \mathrm{~h}$.

Caspase activation is known to be involved in cell death induced by production of ROS. ${ }^{44,46}$ Caspases -9 and 3 are activated when ROS act in mitochondria, triggering events that will culminate in cytochrome c release. Caspase 8 is activated as a consequence of the ROS effects on apoptotic ligands such as the tumor necrosis factorrelated apoptosis-inducing ligand (TRAIL) ${ }^{46,48}$ Putting together all events in a time line, we observed at first a significant rise in PS externalization and production of ROS, and then an activation of caspases 3, 8 and 9. After 72h, cells presented DNA fragmentation and an evenhigher production of ROS. Apoptosis caused by oxidative stress is commonly reported in cells exposed tohigh concentrations of FAs wherein the peroxisomes are the major site of thishydrogen peroxide production. ${ }^{49,50}$

According to the Randle Cycle, also known as the "glucosefatty acid cycle", there is an inverse relationship between fatty acid availability and glucose consumption. ${ }^{51}$ In the fasted state as well as after ahigh-fat meal, the increase in the fatty acid/glucose ratio causes glucose oxidation inhibition; the increase in fatty acid oxidation raises citrate concentration and ATP/ADP ratio, which in turn inhibits phosphofructokinase activity and, consequently, the glycolytic pathway. ${ }^{52}$ Therefore, in a situation of fatty acid deficiency, an increase in glucose oxidation would be expected, as found and as observed in rats with plasma free fatty acids deficiency. ${ }^{53} \mathrm{~A}$ similar pattern of glucose consumption was observed for lipid synthesis. ${ }^{2}$ 
The body of results presentedhere is able to point out to another aspect of FA metabolism in pancreatic beta cells, contributing with the discussion about the consequences of nutrient restriction on the field of pancreatic cells and insulin production, since we present, for the first time,how $\beta$-cells respond to FAs absence. A remaining question from this study is whether there are specific groups, or specific fatty acids that can trigger or counteract the death response observedhere. For that, other studies are necessary to investigate the reposition of FAs, separately, in order to observe if this addition can revert the effects caused by the nutritional restriction.

\section{Conclusion}

Deficiency of FAs promoted increased glucose oxidation most likely in order to maintain energy supply and lipid synthesis. Removal of FAs also caused an increase in production of ROS in pancreatic b-cells, which led to cell death. The combination of DNA fragmentation, phosphatidylserine externalization and activation of caspases suggests an apoptotic mechanism of cell death although loss of membrane integrity was also observed.

\section{Competing interests}

The authors declare that there are no competing interests.

\section{Author contributions}

MPR was responsible for designing and conducting the experiments, analysing the data and writing the manuscript. VAN was responsible for designing the experiments, analysing the data and a major contributor in writing the manuscript. SL was responsible for analysing the data andhelping with the manuscript reviews. $\mathrm{RC}$ was responsible for analysing and discussing the data andhelping with the manuscript reviews. AKAM was responsible for designing the experiments, analysing and discussing the data and a major contributor in writing the manuscript. All authors read and approved the final manuscript and agreed to be accountable for all aspects of the work in ensuring that questions related to the accuracy or integrity of any part of the work are appropriately investigated and resolved. All persons designated as authors qualify for authorship, and all those who qualify for authorship are listed.

\section{Acknowledgements}

We thank Prof. Dr. Sandro Massaohirabara and Dr. Tatiana Carolina Alba Loureiro for their assistance in data acquisition, and Erica Portioli Silva and Lívia Dati for the assistance with cell culture and data acquisition.

\section{Funding}

São Paulo Research Foundation (FAPESP; 2008/54191-3 and 2007/59756-6), The National Council for Scientific and Technological Development $(\mathrm{CNPq})$, Coordination for the Improvement ofhigher Education Personnel (CAPES), and Guggenheim Foundation supported this study.

\section{References}

1. Brown DA, London E. Functions of lipid rafts in biological membranes. Annu Rev Cell Dev Biol. 1998;14:111-136.

2. Keane D, Newsholme P. Saturated and unsaturated (including arachidonic acid) non-esterified fatty acid modulation of insulin secretion from pancreatic beta-cells. Biochem Soc Trans. 2008;36(Pt 5):955-958.

3. Prentki M, Vischer S, Glennon MC, et al. Malonyl-CoA and long chain
acyl-CoA esters as metabolic coupling factors in nutrient-induced insulin secretion. J Biol Chem. 1992;267(9):5802-5810.

4. Koren N, Simsa-Maziel S, Shahar R, et al. Exposure to omega-3 fatty acids at early age accelerate bone growth and improve bone quality. $J$ Nutr Biochem. 2014;25(6):623-633.

5. Hurley MS, Flux C, Salter AM, et al. Effects of fatty acids on skeletal muscle cell differentiation in vitro. Br J Nutr. 2016;95(3):623-630.

6. Zhou H, Liu X, Liu L, et al. Oxidative stress and apoptosis of human brain microvascular endothelial cells induced by free fatty acids. J Int Med Res. 2009;37(6):1897-1903.

7. Bender K, Newsholme P, Brennan L, et al. The importance of redox shuttles to pancreatic beta-cell energy metabolism and function. Biochem Soc Trans. 2006;34(Pt 5):811-814.

8. Jitrapakdee S, Wutthisathapornchai A, Wallace JC, et al. Regulation of insulin secretion: role of mitochondrial signalling. Diabetologia. 2010;53(6):1019-1032.

9. Itoh Y, Kawamata Y, Harada M, et al. Free fatty acids regulate insulin secretion from pancreatic beta cells through GPR40. Nature. 2003;422(6928):173-176.

10. Briscoe CP, Tadayyon M, Andrews JL, et al. The orphan G proteincoupled receptor GPR40 is activated by medium and long chain fatty acids. J Biol Chem. 2003;278(13):11303-11311.

11. Tanaka H, Yoshida S, Minoura H, et al. Novel GPR40 agonist AS2575959 exhibits glucose metabolism improvement and synergistic effect with sitagliptin on insulin and incretin secretion. Life Sci. 2014;94(2):115-121.

12. Yaney GC, Corkey BE. Fatty acid metabolism and insulin secretion in pancreatic beta cells. Diabetologia. 2003;46(10):1297-1312.

13. Deeney JT, Gromada J, Høy M, et al. Acute stimulation with long chain acyl-CoA enhances exocytosis in insulin-secreting cells (HIT T-15 and NMRI beta-cells). J Biol Chem. 2000;275(13):9363-9368.

14. El-Azzouny M, Evans CR, Treutelaar MK, et al. Increased glucose metabolism and glycerolipid formation by fatty acids and GPR40 receptor signaling underlies the fatty acid potentiation of insulin secretion. $J$ Biol Chem. 2014;289(19):13575-13588.

15. Opara EC, Hubbard VS, Burch WM, et al. Characterization of the insulinotropic potency of polyunsaturated fatty acids. Endocrinology. 1992;130(2):657-662.

16. Crespin SR, Greenough WB, Steinberg D. Stimulation of insulin secretion by infusion of free fatty acids. J Clin Invest. 1969;48(10):1934-1943.

17. Jensen CB, Storgaard H, Holst JJ, et al. Insulin secretion and cellular glucose metabolism after prolonged low-grade intralipid infusion in young men. The Journal of Clinical Endocrinology \& Metabolism. 2003;88(6):2775-2783.

18. Kristinsson H, Smith DM, Bergsten P, et al. FFAR1 is involved in both the acute and chronic effects of palmitate on insulin secretion. Endocrinology. 2013;154(11):4078-4088.

19. Lupi R, Dotta F, Marselli L, et al. Prolonged exposure to free fatty acids has cytostatic and pro-apoptotic effects on human pancreatic islets: evidence that beta-cell death is caspase mediated, partially dependent on ceramide pathway, and Bcl-2 regulated. Diabetes. 2002;51(5):1437-1442.

20. Shimabukuro M, Zhou YT, Levi M, et al. Fatty acid-induced beta cell apoptosis: a link between obesity and diabetes. Proc Natl Acad Sci USA. 1998;95(5):2498-2502.

21. Stein DT, Esser V, Stevenson BE, et al. Essentiality of circulating fatty acids for glucose-stimulated insulin secretion in the fasted rat. $J$ Clin Invest.1996;97(12):2728-2735.

22. Wang J, Li Y, Han X, et al. Exposure to the Chinese Famine in Childhood Increases Type 2 Diabetes Risk in Adults. JNutr. 2016;146(11):2289-2295. 
23. Roseboom T, de Rooij S, Painter R. The Dutch famine and its long-term consequences for adult health. Early Hum Dev. 2006;82(8):485-491.

24. Garofano A, Czernichow P, Breant B. Beta-cell mass and proliferation following late fetal and early postnatal malnutrition in the rat. Diabetologia. 1998;41(9):1114-1120.

25. Remacle $\mathrm{C}$, Dumortier O, Bol V, et al. Intrauterine programming of the endocrine pancreas. Diabetes, Obes Metab. 2007;9(s2):196-209.

26. Leighton B, Budohoski L, Lozeman FJ, et al. The effect of prostaglandins E1, E2 and F2 alpha and indomethacin on the sensitivity of glycolysis and glycogen synthesis to insulin in stripped soleus muscles of the rat. Biochem J. 1985;227(1):337-340.

27. Hirabara SM, Folador A, Fiamoncini J, et al. Fish oil supplementation for two generations increases insulin sensitivity in rats. $J$ Nutr Biochem. 2013;24(6):1136-1145.

28. Azevedo-Martins AK, Monteiro AP, Lima CL, et al. Fatty acid-induced toxicity and neutral lipid accumulation in insulin-producing RINm5F cells. Toxicol in Vitro. 2006;20(7):1106-1113.

29. Nicoletti I, Migliorati G, Pagliacci MC, et al. A rapid and simple method for measuring thymocyte apoptosis by propidium iodide staining and flow cytometry. J Immunol Methods. 1991;139(2):271-279.

30. Mosmann T. Rapid colorimetric assay for cellular growth and survival: application to proliferation and cytotoxicity assays. J Immunol Methods. 1983;65(1-2):55-63.

31. Koopman G, Reutelingsperger CP, Kuijten GA, et al. Annexin V for flow cytometric detection of phosphatidylserine expression on B cells undergoing apoptosis. Blood. 1994;84(5):1415-1420.

32. Calder PC, Yaqoob P, Harvey DJ, et al. Incorporation of fatty acids by concanavalin A-stimulated lymphocytes and the effect on fatty acid composition and membrane fluidity. Biochem J. 1994;300(Pt 2):509-518.

33. Healy DA, Wallace FA, Miles EA, et al. Effect of low-to-moderate amounts of dietary fish oil on neutrophil lipid composition and function. Lipids. 2000;35(7):763-768.

34. Kew S, Mesa MD, Tricon S, et al. Effects of oils rich in eicosapentaenoic and docosahexaenoic acids on immune cell composition and function in healthy humans. Am J Clin Nutr. 2004;79(4):674-681.

35. Burr G, Burr M. A new deficiency disease produced by the rigid exclusion of fat from the diet. J Biol Chem. 1929;82(2):345-367.

36. Spector AA. Essentiality of fatty acids. Lipids. 1999;34:S1-S3.

37. Walker CG, West AL, Browning LM, et al. The Pattern of Fatty Acids Displaced by EPA and DHA Following 12 Months Supplementation Varies between Blood Cell and Plasma Fractions. Nutrients. 2015;7(8):6281-6293.

38. Haber EP, Ximenes HMA, Procópio J, et al. Pleiotropic effects of fatty acids on pancreatic beta-cells. J Cell Physiol. 2003;194(1):1-12.
39. Merezak S, Hardikar AA, Yajnik CS, et al. Intrauterine low protein diet increases fetal beta-cell sensitivity to NO and IL-1 beta: the protective role of taurine. J Endocrinol. 2001;171(2):299-308.

40. Berne C. The metabolism of lipids in mouse pancreatic islets. The oxidation of fatty acids and ketone bodies. Biochem J. 1975;152(3):661-666.

41. Saraste A, Pulkki K. Morphologic and biochemical hallmarks of apoptosis. Cardiovasc Res. 2000;45(3):528-537.

42. Lenzen S. Oxidative stress: the vulnerable beta-cell. Biochem Soc Trans. 2008;36(Pt 3):343-347.

43. Nunes VA, Portioli-Sanches EP, Rosim MP, et al. Progesterone induces apoptosis of insulin-secreting cells: insights into the molecular mechanism. J Endocrinol. 2014;221(2):273-284.

44. Moungjaroen J, Nimmannit U, Callery PS, et al. Reactive oxygen species mediate caspase activation and apoptosis induced by lipoic acid in human lung epithelial cancer cells through Bcl-2 down-regulation. J Pharmacol Exp Ther. 2006;319(3):1062-1069.

45. Kannan, Jain. Oxidative stress and apoptosis. Pathophysiology. 2000;7(3):153-163.

46. Lu X, Liu J, Cao X, et al. Native low density lipoprotein induces pancreatic $\beta$ cell apoptosis through generating excess reactive oxygen species. Lipids Health Dis. 2011;10(1):123.

47. Shen HM, Zhang Z, Zhang QF, et al. Reactive oxygen species and caspase activation mediate silica-induced apoptosis in alveolar macrophages. Am J Physiol Lung Cell Mol Physiol. 2001;280(1):L10-L17.

48. Izeradjene K, Douglas L, Tillman DM, et al. Reactive oxygen species regulate caspase activation in tumor necrosis factor-related apoptosisinducing ligand-resistant human colon carcinoma cell lines. Cancer Res. 2005;65(16):7436-7445.

49. Elsner M, Gehrmann W, Lenzen S. Peroxisome-generated hydrogen peroxide as important mediator of lipotoxicity in insulin-producing cells. Diabetes. 2011;60(1):200-208.

50. Gehrmann W, Würdemann W, Plötz T, et al. Antagonism Between Saturated and Unsaturated Fatty Acids in ROS Mediated Lipotoxicity in Rat Insulin-Producing Cells. Cell Physiol Biochem. 2015;36(3):852-865.

51. Randle PJ, Garland PB, Hales CN, et al. The glucose fatty-acid cycle. Its role in insulin sensitivity and the metabolic disturbances of diabetes mellitus. Lancet. 1963;1(7285):785-789.

52. Hue L, Taegtmeyer H. The Randle cycle revisited: a new head for an old hat. Am J Physiol Endocrinol Metab. 2009;297(3):E578-E591.

53. Figueira TR, Ribeiro RA, Ignacio-Souza LM, et al. Enhanced insulin secretion and glucose tolerance in rats exhibiting low plasma free fatty acid levels and hypertriglyceridaemia due to congenital albumin deficiency. Exp Physiol. 2012;97(4):525-533. 